\title{
Rancang Bangun Bioelectrical Impedance Analysis (BIA) Multifrekuensi berbasis ARM
}

\section{Design of ARM-based Multi-Frequency Bioelectrical Impedance Analysis (BIA)}

\author{
Afin M Nurtsani ${ }^{1}$, Baron Murianda ${ }^{2}$, Teguh Prakoso ${ }^{3}$, Yuli Christyono ${ }^{4}$, Munawar A Riyadi ${ }^{5 *}$ \\ Departemen Teknik Elektro, Universitas Diponegoro \\ Jl. Prof. Sudharto, SH, Kampus UNDIP Tembalang, Semarang 50275, Indonesia \\ munawar@elektro.undip.ac.id ${ }^{5 *}$
}

\begin{abstract}
Abstrak - Timbangan badan biasa tidak dapat membedakan antara massa lemak dan massa non lemak. Oleh karena itu, dibutuhkan suatu alat pengukuran yang mampu membedakan massa lemak dan massa non lemak. Untuk mengetahui komposisi tubuh, digunakan metode Bioelectrical Impedance Analysis (BIA) yang memiliki keunggulan yaitu murah, mudah, dan portable. Penggunaan frekuensi yang berbeda pada BIA memberi kelebihan pada kemampuan segmentasi. Untuk itu, pada penelitian ini, dilakukan rancang bangun BIA yang bekerja pada beberapa frekuensi berbeda, yaitu Multi Frequency Bioelectrical Impedance Analysis (MFBIA). Sistem pengolahan sinyal BIA dirancang berbasis ARMSTM32F103C8T6. Hasil penelitian menunjukkan bahwa sistem pengolah sinyal dapat menghasilkan data persentase lemak tubuh. Galat relatif dari sistem pengolah sinyal sebesar 9,926\% pada metode Hand-to-Hand, dibandingkan terhadap alat pembanding komersial sejenis.
\end{abstract}

Kata kunci: Multi Frequency Bioelectrical Impedance Analysis (MFBIA), persentasi lemak tubuh, pengolah sinyal, $A R M$

\begin{abstract}
The common weight scales cannot differentiate between fat mass and fat-free mass. Therefore, a measurement tool that is able to differentiate fat mass and fat-free mass is required. To assess body composition assessment, Bioelectrical Impedance Analysis (BIA) method is applied asit is cheap, easy, and portable. The use of different frequency in BIA offers benefit of segmentation ability. Therefore, this research aims to design a BIA which work on several different frequencies, called Multi Frequency Bioelectrical Impedance Analysis (MFBIA). The BIA signal processing system is designed based on based on ARM STM32F103CT6. The result shows that the system can produce the data of body fat percentage. Relative error of signal processing system are $9.926 \%$ for Hand-to-Hand method.
\end{abstract}

Keywords: Multi Frequency Bioelectrical Impedance Analysis (MFBIA), body fat percentage, signal processing, ARM

\section{Pendahuluan}

Pengukuran berat badan menggunakan timbangan biasa tidak dapat membedakan antara massa lemak (fat mass - FM) dan dan massa non lemak (fat-free mass - FFM). Padahal kelebihan lemak meningkatkan kemungkinan terserang penyakit, seperti diabetes tipe 2 , masalah jantung

TELKA, Vol.5, No.2, November 2019, pp. 147 155

ISSN (e): 2540-9123

ISSN (p): 2502-1982 
dan kanker. Komposisi tubuh apabila diketahui dengan baik akan memudahkan tindakan lebih lanjut untuk menjaga kesehatan[1]. Oleh karena itu dibutuhkan suatu alat pengukuran yang mampu membedakan massa lemak dan massa non lemak, yang dapat mengetahui masa lemak dan masa non lemak yang menyusun berat[1]. Bioelectric Impedance Analysis (BIA) sebagai salah satu metode analisis komposisi tubuh banyak digunakan untuk mengetahui masa lemak tubuh. Hal ini karena BIA mudah digunakan, cepat, non-invasive, portable, dan dapat dioperasikan sendiri [1 - 2]. Selain itu BIA juga lebih akurat dibandingkan caliper tests, lebih mudah digunakan daripada densitometry dan lebih aman dari dual energy x-ray absorpiometry (DXA)[3].

Pengukuran menggunakan BIA memodelkan tubuh manusia menjadi sebuah rangkaian listrik sederhana yang terdiri dari resistor dan kapasitor [2]. Impedansi tubuh manusia dapat diukur dengan memberikan arus bolak-balik (AC) ke tubuh melalui elektroda. Pada umumnya, arus yang digunakan adalah sebesar $0,1 \mathrm{~mA}$ dengan frekuensi sebesar $50 \mathrm{kHz}[2]$. Berdasarkan hasil percobaan hubungan reaktansi, resistansi, dan frekuensi pada tubuh manusia, nilai resistansi pada frekuensi tertentu dapat diketahui [3]. Besarnya nilai frekuensi yang digunakan mempengaruhi aliran arus yang masuk pada tubuh manusia. Pada frekuensi rendah antara $1-5$ $\mathrm{kHz}$ aliran arus sulit menembus membran sel sehingga hanya mengalir pada cairan ekstraselular. Dengan menaikkan frekuensi maka aliran arus dapat menembus membran sel sehingga dapat mengalir melewati cairan intraselular. Pada frekuensi $50 \mathrm{kHz}$ arus yang mengalir mengalami sedikit pembelokan ketika melewati membran sel, sementara untuk frekuensi $100 \mathrm{kHz}$ aliran arus melewati membran sel [4]. Berdasarkan hasil percobaan hubungan reaktansi, resistansi, dan frekuensi oleh Elizabeth Mylott dkk[3] nilai resistansi pada frekuensi tertentu dapat diketahui.

Beberapa penelitian sebelumnya menunjukkan bahwa impedansi tubuh menggunakan BIA dengan beberapa frekuensi bermanfaat meningkatkan identifikasi komposisi tubuh $[5,6]$. Pada penelitian sebelumnya [7], telah dibuat sebuah modul BIA dengan menggunakan empat elektroda, yaitu kedua tangan yang berbentuk hand grip dan juga kedua kaki berbentuk papan dengan lempengan elektroda berada di permukaan papan tersebut. Sementara itu, telah dibuat juga modul BIA yang dapat mengubah input elektroda dan output dengan otomatis tanpa harus melepaskan dan menyambungkan sambungan elektroda kepada alat utama BIA [8]. Namun kedua penelitian tersebut hanya memanfaatkan frekuensi $50 \mathrm{kHz}$. Dengan basis rancang bangun berasal dari penelitian sebelumnya[4], maka penelitian ini membangun suatu sistem BIA multi frekuensi yang disebut Multi Frequency Bioelectrical Impedance Analysis (MFBIA) dengan berbasis mikrokontroler ARM STM32F103C8T6 untuk mendapatkan nilai Body Fat (BF) yang lebih akurat.

\section{Metode}

\subsection{Perancangan Perangkat Keras}

Diagram blok perancangan perangkat keras pengolahan sinyal MFBIA secara keseluruhan dapat dilihat pada Gambar 1. Perangkat keras dirancang untuk menghitung dan memasukan nilai yang dibutuhkan serta menampilkan data body fat yang sudah dihitung. Blok sistem dibagi dalam beberapa subsistem, yaitu subsistem Power Supply, subsistem Variable Sine Wave Generator, yaitu subsistem Electrode Switch, dan subsistem Pengolah Sinyal dan Antarmuka Pengguna. Subsistem Power Supply berfungsi sebagai penyedia catu daya listrik pada produk ini. Subsistem ini bertujuan untuk memberikan daya untuk keseluruhan subsistem di produk ini. Subsistem ini dirancang agar dapat mengisi kembali baterai sehingga dapat digunakan secara portable. Serta dirancang perlindungan terhadap over charprocege dan over discharge agar baterai mempunyai jangka pakai yang Panjang. Subsistem Variable Sine Wave Generator berfungsi untuk menghasilkan sinyal berarus konstan dengan frekuensi yang dapat diatur dengan nilai $25 \mathrm{kHz}, 50$ $\mathrm{kHz}$, dan $100 \mathrm{kHz}$. Pada subsistem ini menggunakan komponen IC Sine Wave Generator (IC 4066), Amplifier, dan Voltage Controled Current Source (IC LF353N), dengan pengaturan frekuensi menggunakan switching untuk mengatur besar resistansi yang terhubung ke IC 4066. Selain itu, nilai arus yang dihasilkan ditentukan sebesar $0,1 \mathrm{~mA}$ pada perangkat ini, diatur agar tidak melebihi ambang batas aman $1 \mathrm{~mA}$ [9]. Subsistem Electrode Switch berfungsi sebagai

ISSN (e): 2540-9123

ISSN (p): 2502-1982 
pengatur elektroda-elektroda yang terhubung antara tubuh pengguna dengan perangkat pembaca impedansi. Subsistem ini bertujuan untuk mengendalikan empat elektroda (di setiap tangan dan kaki) yang dipakai untuk mengukur nilai impedansi tubuh. Subsistem Pengolah Sinyal dan Antarmuka Pengguna berfungsi untuk mengolah sinyal masukan dari elektroda sehingga dapat dibaca oleh mikrokontroler, serta sebagai antarmuka antar produk dan juga pengguna. Antarmuka pengguna meliputi pemasukan data pengguna yang dibutuhkan untuk perhitungan impedansi tubuh, pengaturan frekuensi dan elektroda, serta menampilkan nilai yang sudah diproses melalui LCD sebagai media penampil.

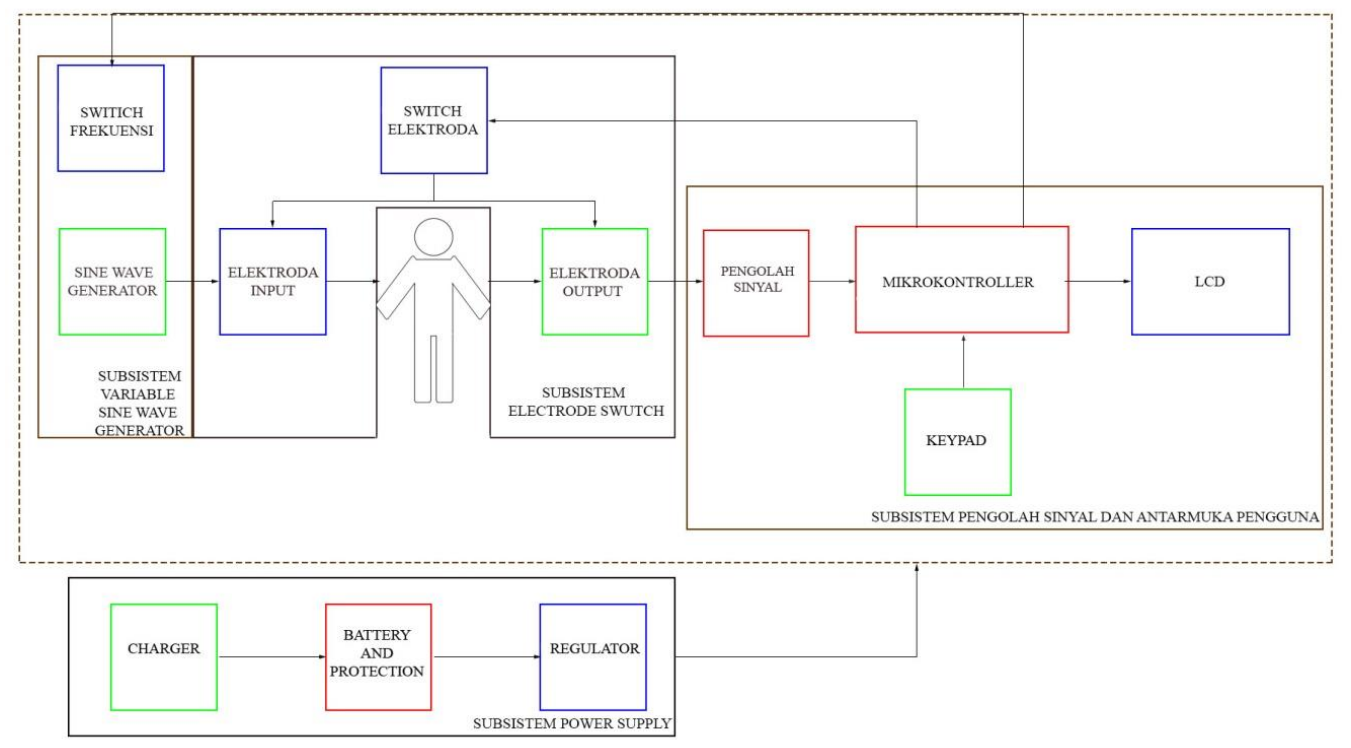

Gambar 1. Blok diagram sistem

\subsection{Penentuan Persentase Lemak Tubuh}

Untuk menentukan nilai persentase lemak tubuh (Body Fat - BF) dibutuhkan nilai massa tubuh tanpa lemak (fat-free mass - FFM) terlebih dahulu. Perhitungan nilai FFM didapat dengan data yang telah dimasukan dengan persamaan dari P. Durenberg et al[10] dengan kofisien kolerasi tertinggi. Rumus FFM diperoleh sesuai dengan Persamaan 1 berikut

$$
F F M=\left(0.513 \frac{h^{2}}{R}\right)+0.359 h+0.392 w-2.6851 a+16.622
$$

dimana $h$ adalah tinggi tubuh (dalam $\mathrm{cm}$ ), $R$ adalah impedansi tubuh (dalam Ohm), $w$ adalah berat tubuh (dalam $\mathrm{kg}$ ) dan $a$ adalah umur (dalam tahun). Setelah didapatkan nilai FFM maka didapat nilai massa lemak (fat mass - FM) dan BF dengan Persamaan 2 dan 3[11]:

$$
\begin{gathered}
F M=w-F F M \\
B F=\frac{F M}{w} \times 100 \%
\end{gathered}
$$

Dengan demikian, berdasar persamaan (1), pengukuran impedansi tubuh R menjadi krusial dalam penentuan persentase lemak tubuh (BF). Selain itu, nilai berat tubuh, tinggi dan umur dimasukkan oleh pengguna menggunakan antarmuka keypad (tidak dihitung langsung oleh sistem). 


\subsection{Pengolahan Sinyal Untuk Menentukan Impedansi Tubuh}

Pengolahan sinyal bermula dari pengukuran tegangan dari dua elektroda, dimana arus bolakbalik berfrekuensi tertentu dialirkan di antara kedua elektroda tersebut. Karena tegangan yang terukur kecil (dalam orde millivolt), maka diperlukan rangkaian berikut:

\section{a. Instrumentation Amplifier}

Instrumentation Amplifier adalah sebuah jenis penguat diferensial yang telah dilengkapi dengan buffer, sehingga menghilangkan kebutuhan untuk pencocokan impedansi masukan. Pada perancangan ini, dipilih IC AD620A yang bekerja pada tegangan kerja $12 \mathrm{~V}$ dan berfungsi untuk menguatkan sinyal tegangan dari elektroda hasil pengukuran dari tubuh.

\section{b. Multiple Feedback Band Pass Filter (MFBPF)}

MFBPF adalah salah satu topologi tapis orde dua yang dapat digunakan untuk menyusun sebuah tapis. Konfigurasi topologi MFBPF bergantung pada nilai kualitas filter dan gain dari rangkaian itu, seperti ditunjukkan pada Gambar 2. Perancangan rangkaian MFBPF pada produk ini dibutuhkan dapat menapis dengan di daerah frekuensi tengah tapis berada pada tiga frekuensi yang menjadi acuan percobaan pada produk ini yaitu, $25 \mathrm{kHz}, 50 \mathrm{kHz}$, dan $100 \mathrm{kHz}$. Nilai frekuensi cut-off, gain, kualitas filter, dan bandwidth diperoleh dari pemilihan nilai $\mathrm{R}$ dan $\mathrm{C}$ di Gambar 2, berdasar Persamaan (4) - (7) berikut:

$$
\begin{gathered}
f_{m}=\frac{1}{2 \pi C} \sqrt{\frac{R_{1}+R_{3}}{R_{1} R_{2} R_{3}}} \\
A_{m}=\frac{R_{2}}{2 R_{1}} \\
Q \quad=\pi f_{m} R_{2} C \\
B=\frac{1}{\pi R_{2} C}
\end{gathered}
$$

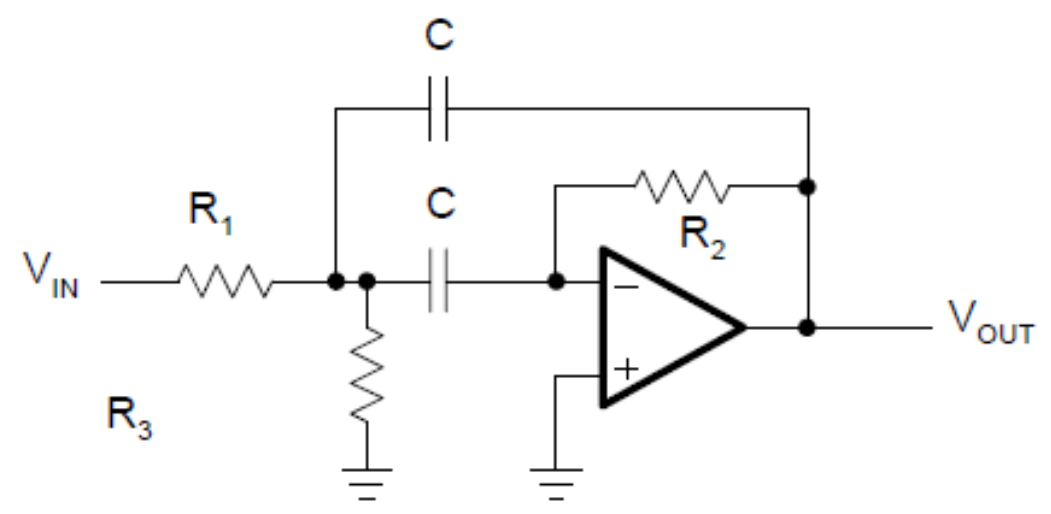

Gambar 2. Rangkaian Multiple Feedback Band Pass Filter

Untuk rancangan ini, nilai $\mathrm{R} 1$ dan $\mathrm{R} 2$ bernilai $3,4 k \Omega$ dan $6,8 \mathrm{k} \Omega$, sementara nilai R3 untuk frekuensi 25, 50 dan $100 \mathrm{kHz}$ masing-masing adalah $606 \Omega, 150 \Omega$ dan $38 \Omega$.

\section{c. Precision Full Wave Rectifier}

Precision Full Wave Rectifier adalah topologi penyearah gelombang penuh yang dirancang menggunakan Op-Amp sehingga dapat melewati dibawah nilai threshold dioda. Konfigurasi umumnya ditunjukkan pada Gambar 3. 


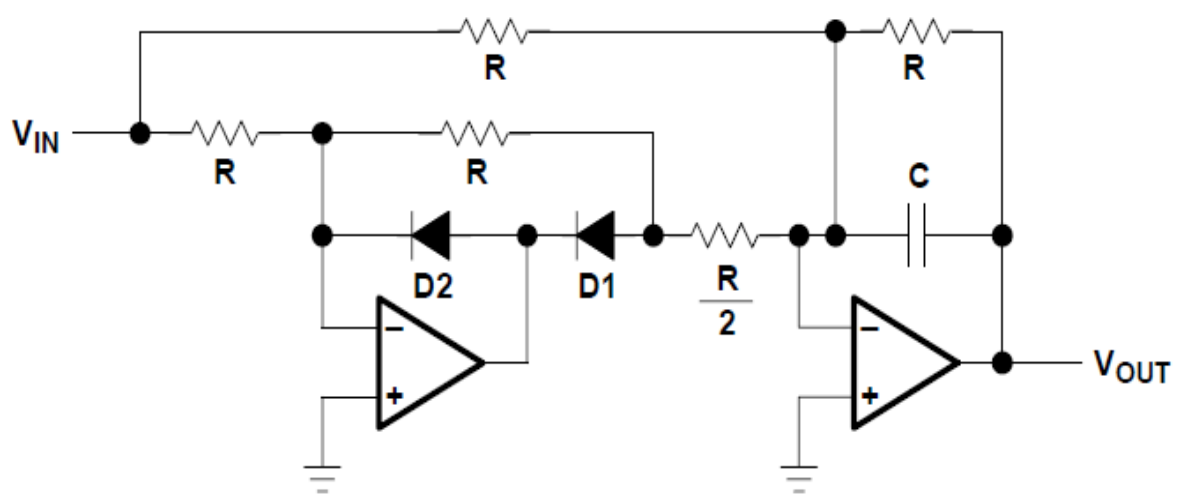

Gambar 3. Konfigurasi umum Precision Full-Wave Rectifier[12]

\subsection{Perancangan Perangkat Lunak}

Perancangan perangkat lunak pada modul pengolah sinyal MFBIA ini berisi algoritma dan diagram alir sistem serta prosedur pemrograman dalam sistem pengolahan sinyal dan pemasukan data yang akan masuk ke dalam mikrokontroler STM32F103C8T6 [13]. Bahasa pemrograman yang digunakan adalah bahasa C dengan program compiler AC6 System Workbench. Secara umum algoritma purwarupa MFBIA adalah sebagai berikut:

1. Mulai.

2. Inisialisasi I/O register dan variabel.

3. Inisialisasi dan deteksi LCD, Keypad dan ADC.

4. Deteksi masukan data tinggi, berat, umur dan jenis kelamin melalui keypad sebagai sarana masukan data. Apabila data tidak sesuai maka akan dikembalikan pada proses ini kembali.

5. Deteksi masukan frekuensi dan probe melalui keypad sebagai sarana masukan data. Apabila data tidak sesuai maka akan dikembalikan pada proses ini kembali.

6. Mulai Pengukuran melalui probe.

7. Menghitung nilai BMI dan status BMI melalui LCD.

8. Jika dibutuhkan pengukuran kembali maka akan dikembalikan ke langkah f. Jika tidak maka dilanjutkan ke langkah berikutnya

9. Selesai.

Diagram alir algoritma yang telah dijabarkan sebelumnya dapat dilihat pada Gambar 4 .

\section{Hasil dan Analisis}

\subsection{Pengujian filter MFBPF}

Pengujian ini dilakukan untuk mengetahui apakah kinerja MFBPF untuk mencegah sinyal yang tidak diinginkan ikut terukur dalam sistem bekerja dengan baik. Pengujian dilakukan dengan pengukuran rangkaian MFBPF untuk nilai input $1600 \mathrm{mV}$. Pengujian dilakukan sebanyak 3 kali dengan frekuensi tengah yang dirancang masing-masing $25 \mathrm{kHz}, 50 \mathrm{kHz}$, dan $100 \mathrm{kHz}$. Hasil pengujian untuk masing-masing frekuensi dapat dilihat pada Tabel 1-3. Hasil yang sama disajikan pada Gambar 5-7, namun dalam nilai gain, yang diperoleh dari

$$
\text { Gain }=20 \log \left(\frac{\text { Vout }}{\text { Vin }}\right)
$$



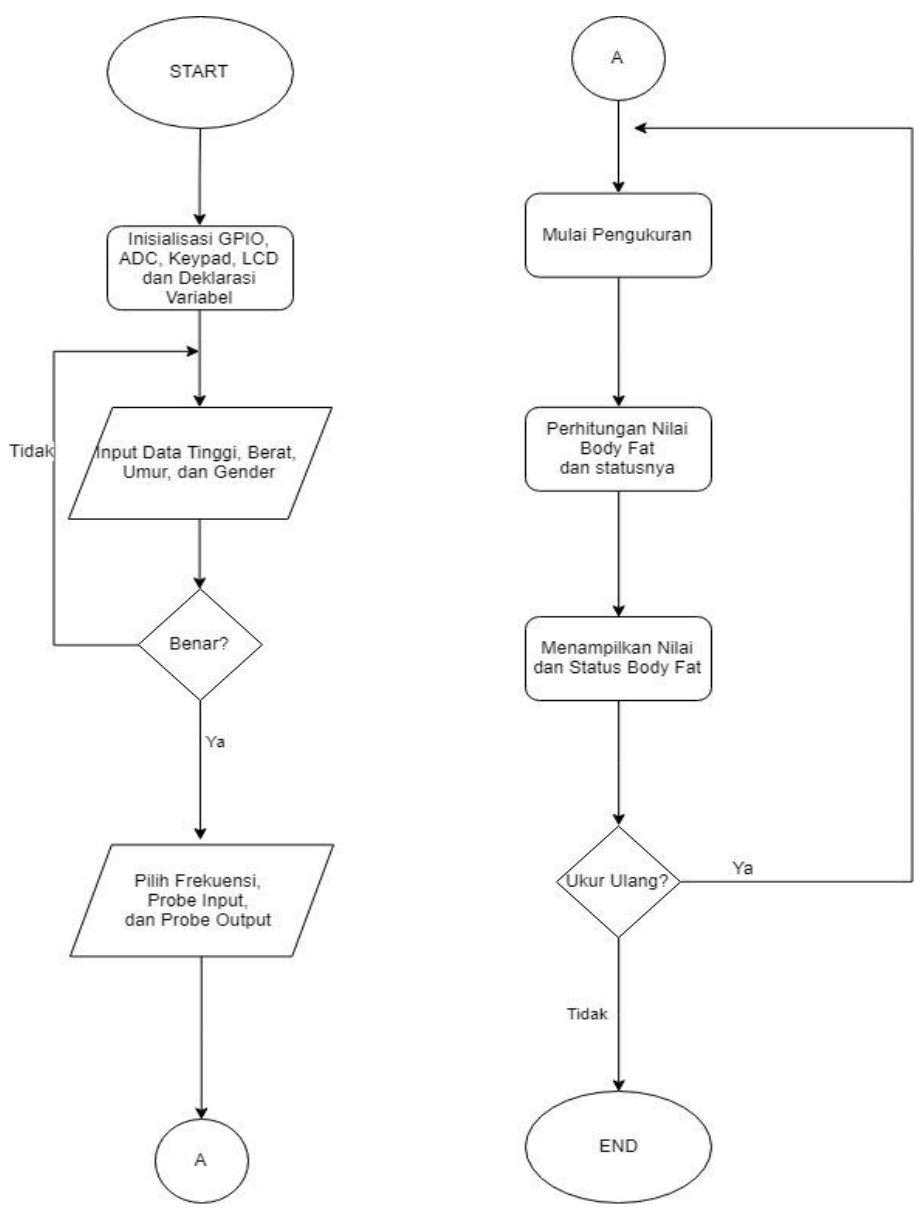

Gambar 4. Diagram alir pada pengolahan sinyal MFBIA di STM32F103C8T6

Tabel 1. Kinerja MFBPF untuk $f_{c}=25 \mathrm{kHz}$

\begin{tabular}{cccc}
\hline No & Vin $(\mathrm{mV})$ & $\mathrm{F}(\mathrm{KHz})$ & Vout $(\mathrm{mV})$ \\
\hline 1 & 1600 & 1 & 200 \\
2 & 1600 & 25 & 1840 \\
3 & 1600 & 50 & 5760 \\
4 & 1600 & 75 & 1600 \\
5 & 1600 & 100 & 1240 \\
6 & 1600 & 125 & 960 \\
7 & 1600 & 150 & 1020 \\
8 & 1600 & 200 & 680
\end{tabular}

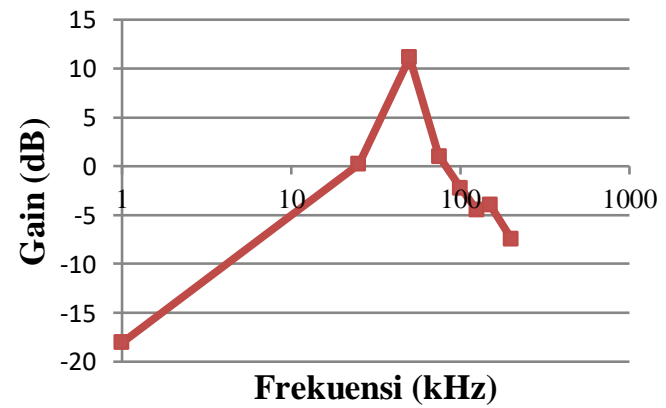

Gambar 5. Pengukuran MFBPF untuk $f_{c}=25 \mathrm{kHz}$

Tabel 2. Kinerja MFBPF untuk $f_{c}=50 \mathrm{kHz}$

\begin{tabular}{cccc}
\hline No & Vin $(\mathrm{mV})$ & $\mathrm{F}(\mathrm{KHz})$ & Vout $(\mathrm{mV})$ \\
\hline 1 & 1600 & 1 & 200 \\
2 & 1600 & 25 & 680 \\
3 & 1600 & 50 & 1640 \\
4 & 1600 & 75 & 4600 \\
5 & 1600 & 100 & 1480 \\
6 & 1600 & 125 & 1000 \\
7 & 1600 & 150 & 1000 \\
8 & 1600 & 200 & 480 \\
\hline
\end{tabular}

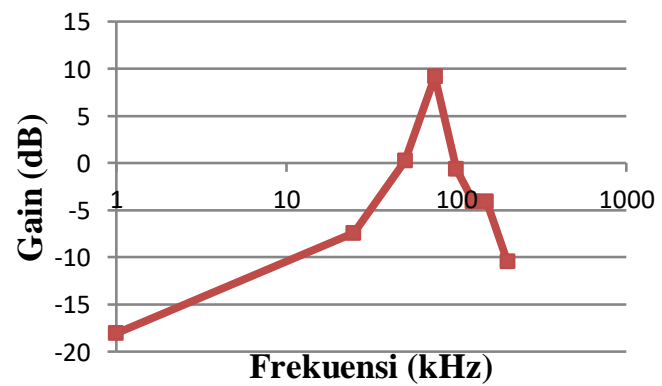

Gambar 6. Pengukuran MFBPF untuk $f_{c}=50 \mathrm{kHz}$ 
Tabel 3. Kinerja MFBPF untuk $f_{c}=100 \mathrm{kHz}$

\begin{tabular}{cccc}
\hline No & Vin $(\mathrm{mV})$ & $\mathrm{F}(\mathrm{KHz})$ & Vout $(\mathrm{mV})$ \\
\hline 1 & 1600 & 1 & 200 \\
2 & 1600 & 25 & 560 \\
3 & 1600 & 50 & 1440 \\
4 & 1600 & 75 & 4860 \\
5 & 1600 & 100 & 2400 \\
6 & 1600 & 125 & 1000 \\
7 & 1600 & 150 & 1020 \\
8 & 1600 & 200 & 480 \\
\hline
\end{tabular}

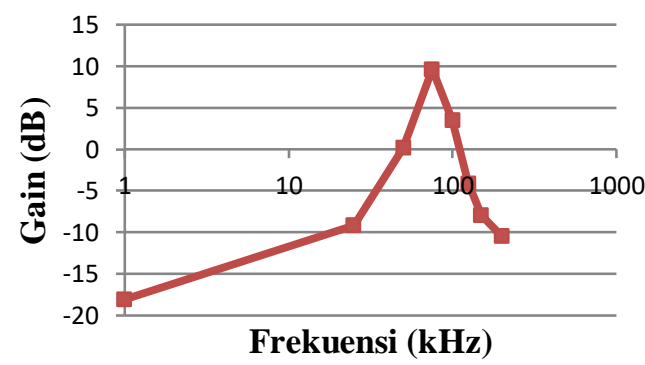

Gambar 7. Pengukuran MFBPF untuk $f_{c}=100 \mathrm{kHz}$

Hasil yang ditunjukkan pada Gambar 5-7 menunjukkan nilai frekuensi tengah untuk tiap rancangan. Pada MFBPF untuk $f_{c}=25 \mathrm{kHz}$, frekuensi tengah berada antara $25-50 \mathrm{kHz}$, untuk $f_{c}=50$ $\mathrm{kHz}$, nilai tengah berada di $50 \mathrm{kHz}$, dan untuk $f_{c}=100 \mathrm{kHz}$, nilai tengah berada antara $75-100 \mathrm{kHz}$. Terdapat pergeseran frekuensi tengah terhadap perancangan, namun demikian nilai tengah yang dirancang masih berada di daerah yang dicakup oleh BPF tersebut. Dengan demikian, MFBPF dapat digunakan untuk keperluan penapisan sinyal derau.

\subsection{Pengujian Linearitas Penguatan}

Pengujian linearitas penguatan instrumentation amplifier terhadap beban impedansi terukur ditunjukkan pada Gambar 8, untuk frekuensi 25, 50 dan $100 \mathrm{kHz}$. Hasil pengujian menunjukkan bahwa linearitas sistem sangat baik, dengan koefisien regresi $\mathrm{R}=0,9988$. Pengaruh kenaikan tegangan hanya terjadi karena pengaruh kenaikan resistansi yang dideteksi, dalam hal ini impedansi tubuh manusia. Dengan demikian, besar tegangan keluaran Vout dapat dikalkulasi secara langsung untuk menghitung impedansi tubuh, dan pada gilirannya menghitung massa lemak tubuh, seperti ditunjukkan pada Persamaan (1) - (3).

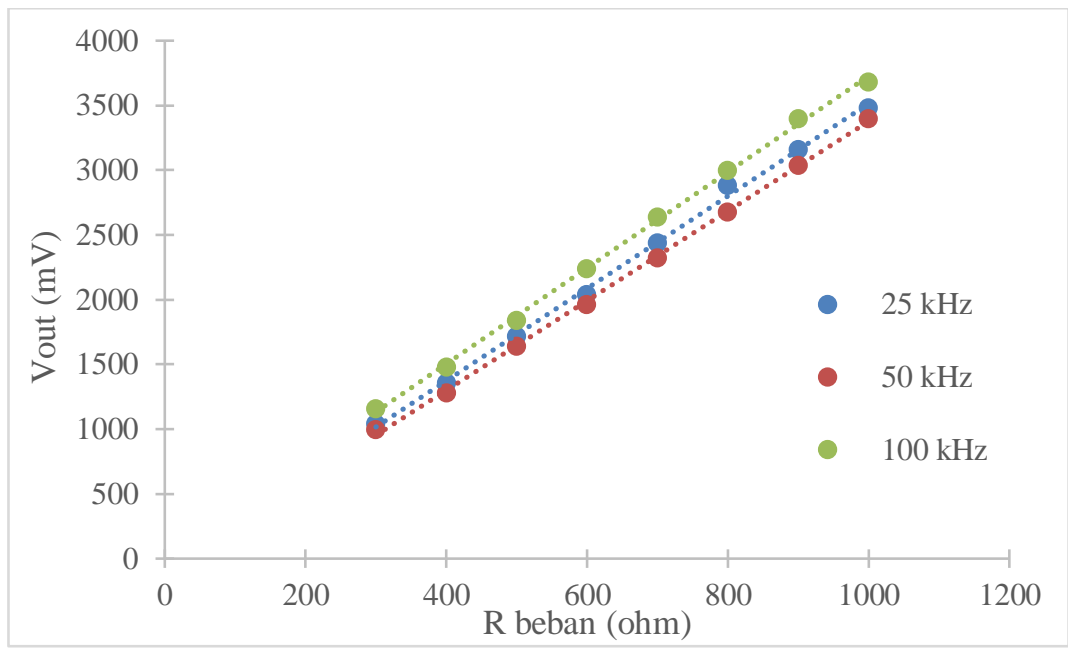

Gambar 8. Pengukuran linieritas penguatan.

\subsection{Pengujian Pengukuran Persentase Lemak Tubuh}

Pengujian ini dilakukan untuk mengetahui keakuratan alat. Pengujian dilakukan dengan membandingkan hasil pengukuran persentase lemak tubuh alat yang menggunakan metode hand to hand $(\mathrm{H}$ to $\mathrm{H})$ dengan hasil pengukuran persentase lemak tubuh menggunakan KARADA SCAN HBF375 yang memakai metode pengukuran whole body measurement. Pada pengujian Metode Hand-to-Hand, elektroda ditempatkan pada tangan kiri dan tangan kanan. Pada pengujian 
ini arus dialirkan di antara telapak tangan kiri dan kanan lalu tegangan yang dihasilkan diukur. Hasil pengujian dapat dilihat pada Tabel 4, untuk setiap frekuensi.

Tabel 4. Hasil metode Hand-to-Hand.

\begin{tabular}{|c|c|c|c|c|c|c|c|}
\hline \multirow{2}{*}{ Sampel } & \multirow{2}{*}{$\begin{array}{l}\text { TB } \\
(\mathrm{cm})\end{array}$} & \multirow{2}{*}{$\begin{array}{l}\mathrm{BB} \\
(\mathrm{kg})\end{array}$} & \multirow{2}{*}{$\underset{\text { (thn) }}{U}$} & \multirow{2}{*}{$\begin{array}{l}\text { BF(\%) } \\
\text { HBF375 }\end{array}$} & \multicolumn{3}{|c|}{ Body Fat (\%) } \\
\hline & & & & & $25 \mathrm{kHz}$ & $50 \mathrm{kHz}$ & $100 \mathrm{kHz}$ \\
\hline Sample 1 & 173 & 59 & 24 & 9,6 & 5 & 8,4 & 4,8 \\
\hline Sample 2 & 174 & 74 & 25 & 19,8 & 21,5 & 22,7 & 19,1 \\
\hline Sample 3 & 168 & 72 & 25 & 23,4 & 25,8 & 27 & 25,3 \\
\hline Sample 4 & 174 & 77 & 25 & 25,2 & 22,5 & 24,9 & 20,4 \\
\hline Sample 5 & 165 & 78 & 24 & 26,4 & 27,3 & 28,3 & 26,9 \\
\hline Sample 6 & 165 & 74 & 25 & 28 & 28,8 & 29,9 & 26,3 \\
\hline Sample 7 & 175 & 93 & 25 & 28,9 & 30,1 & 31,2 & 29,7 \\
\hline
\end{tabular}

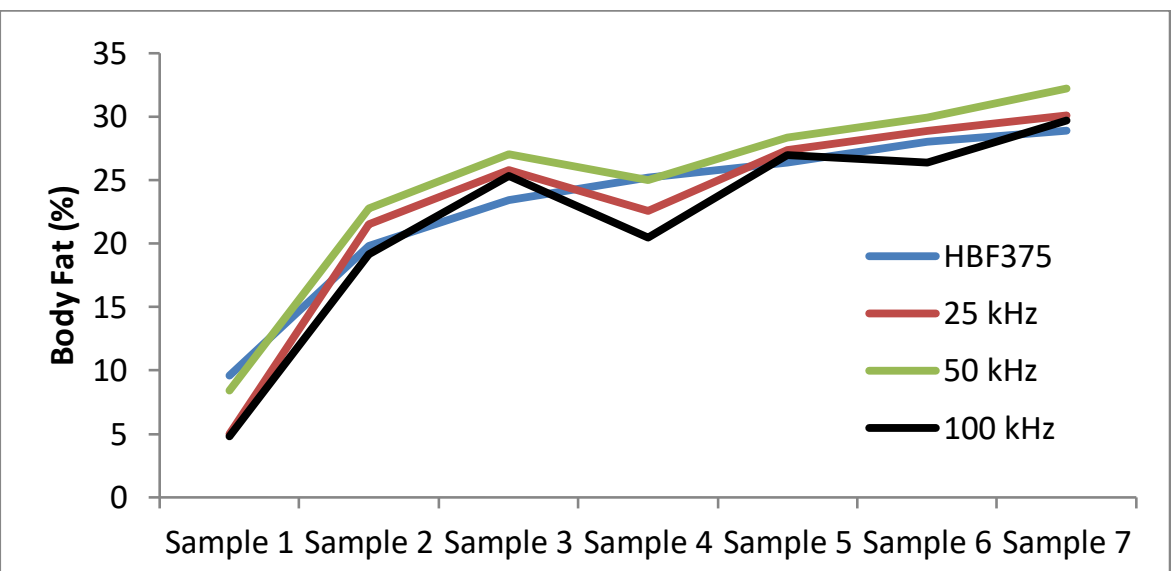

Gambar 9. Perbandingan pengukuran Body Fat tiap frekuensi dan HBF375.

Dapat dilihat pada Tabel 4 bahwa terdapat perbedaan nilai Body Fat yang bervariasi untuk tiap frekuensi. Galat rata-rata relatif terbesar dari alat adalah 15,5\% (untuk nilai BF 9,6\%) dan galat relatif terkecil adalah $2 \%$ pada BF 26,4\%, dengan rata-rata galat 9,926\% terhadap nilai BF yangterukur. Dari Tabel 4 dapat ditunjukkan grafik perbedaan hasil pengukuran Body Fat sesuai dengan Gambar 9.

Secara umum, pengujian menunjukkan bahwa terdapat perbedaan untuk tiap frekuensi, dengan kenderungan frekuensi $50 \mathrm{kHz}$ lebih besar dibandingkan dengan frekuensi 25 dan 100 kHz. Hal ini bersesuaian dengan peta impedansi yang ditunjukkan oleh Cole-Cole Plot [3, 9], dimana kecenderungan puncak impedansi diperoleh pada $50 \mathrm{kHz}$. Selain itu, dengan melihat postur tubuh (tinggi badan subjek) dan beratnya, maka variasi nilai Body Fat untuk frekuensi sinyal yang berbeda-beda ini dapat digunakan untuk penelitian lebih lanjut yang berkaitan dengan segmentasi tubuh, sebagaimana direkomendasikan pada Ref. [5].

\section{Kesimpulan}

Perancangan Multiple Frequency Bielectrical Impedance Analysis telah dilakukan, dan telah diuji dan dianalisis kinerjanya. Pengujian Multiple Feedback Bandpass Filter menunjukkan bahwa tapis telah dapat bekerja walau terdapat pergeseran dalam nilai frekuensi tengah. Linearitas sistem pengolah sinyal mempunyai hubungan antara resistansi tubuh dan tegangan keluaran yang stabil dengan rata-rata koefisien regresi 0,9988. Selain itu, nilai persentase lemak tubuh dari pengolahan sistem dengan metode hand-to-hand mendekati nilai dari alat pembanding dengan galat sebesar 9,926\%. Dengan demikian, sistem ini telah dapat menunjukkan hasil yang baik. 
Hasil dari penelitian ini dapat dikembangkan untuk pengukuran Total Body Water (TBW), Extracelullar Water (ECW), dan Intercelullar Water (ICW).

\section{Referensi}

[1] Lee, Seon Yeong, Dympna Gallagher. "Assessment methods in human body composition." Current opinion in clinical nutrition and metabolic care, vol. 11, no. 5, hal. 566, 2008.

[2] SZ Yanovski, VS. Hubbard, SB Heymsfield, HC. Lukaski. "Bioelectrical impedance analysis in body composition measurement: National institutes of health technology assessment conference statement." The American Journal of Clinical Nutrition vol. 64, no. 3 hal. 524S-532S, 1996.

[3] E. Mylott, E. M. Kutschera, R. Widenhorn, "Bioelectrical Impedance Analysis as a Laboratory Activity: At the Interface of Physics and the Body," American Journal of Physics, vol. 82, no. 5, pp. 521-528, 2014.

[4] R. Dörhöfer, Matthias Pirlich, The BIA Compendium, Data Input GmbH, 2005.

[5] Jukka A Salmi, "Body Composition Assesment With Segmental Multifrequency Bioimpedance Method," J. Sports Sci. Med., vol. 2, no.3, hal. 1-29, September, 2003.

[6] S. F. Khalil, M. S. Mohktar, and F. Ibrahim, "The Theory and Fundamentals of Bioimpedance Analysis in Clinical Status Monitoring and Diagnosis of Diseases," Sensors, pp. 10895-10928, 2014

[7] M.A. Riyadi., A. Nugraha, M. B. Santoso, D. Septaditya, and T. Prakoso. "Development of Bio-impedance Analyzer (BIA) for Body Fat Calculation." In IOP Conference Series: Materials Science and Engineering, vol. 190, no. 1, p. 012018. IOP Publishing, 2017.

[8] M.A. Riyadi, A.N. Muthouwali, and T. Prakoso. "Design of automatic switching bioimpedance analysis (BIA) for body fat measurement." In 2017 4th International Conference on Electrical Engineering, Computer Science and Informatics (EECSI), pp. 1-5. IEEE, 2017.

[9] U. G. Kyle, I. Bosaeus, A. D. De Lorenzo, G. Manuel, B. Lilienthal, L. Kent-smith, J. Melchior, C. Pichard, and W. Group, "Bioelectrical impedance analysis part I : review of principles and methods," Clin. Nutr., pp. 1226-1243, 2004

[10] Deurenberg, P., van der Kooy, K.; Leenen, R.;Weststrate, J.A.; Seidell, J.C. "Sex and age specific prediction formulas for estimating body composition from bioelectrical impedance: A cross-validation study", Int. J. Obes, 1991

[11] M S R Joshi, P U R Bagal. Development of Bioelectrical Impedance Analyzer For Body Composition Analysis. IOSR-JEEE. 2014;9(5):53-62

[12] Texas Instruments, "Design Reference," in Op Amps fot Everyone, no. August, Ron Mancini, Ed. 2002

[13] "STM32F103x8" STMicroelectronics N.V., Geneva, Switzerland, 2015 